\title{
Narratives of long-term resilience: two cases of women aging with spinal cord injury
}

\author{
Edward J. Rohn ${ }^{1} \cdot$ Andrea L. Nevedal $^{2} \cdot$ Denise G. Tate ${ }^{3}$ \\ Received: 16 October 2019 / Revised: 17 March 2020 / Accepted: 18 March 2020 \\ (๑) International Spinal Cord Society 2020
}

\begin{abstract}
Introduction Spinal cord injury (SCI) is a life-changing event that drastically affects a person's sense of identity, ability to participate, and quality of life (QOL). Researchers studying the coping process have often focused on identifying maladaptive behaviors and barriers, and less on positive psychology approaches emphasizing individual strengths. More recently, positive psychology constructs, such as resilience, have received greater attention from SCI researchers. Early and ongoing recognition of resilience in patients with SCI may provide important information to clinicians about adjustment and longterm management. Our purpose is to document patterns and indicators of resilience, using a narrative approach, during various stages of adjustment following SCI.

Case presentations Narrative case presentations are deriving from in-depth qualitative interviews with two women aged 63 and 52 , living with SCI. Both had complete motor neurological injuries that incurred at 27 and 35 years, respectively. Each woman was interviewed twice, approximately 10 years apart (age 63 and 52, and age 54 and 42). Each demonstrated high levels of resilience through evolving roles of family and caregivers, inner personal strength, and participation in their respective communities. We highlight differences, similarities, and evolution of resilience factors in and between each case.

Discussion These cases illustrate examples of long-term resilience, adding richness to the resilience construct. Results provide knowledge that can be used to target rehabilitation interventions toward successful coping styles. In sharing these cases, we hope to assist clinicians and researchers to better recognize patterns of resilience in their own patients and study participants.
\end{abstract}

\section{Introduction}

Spinal cord injury (SCI) is an unforeseen life-changing event that alters a person's ability to function in daily life, including significant limits on motor and sensory function, bladder and bowel dysfunction, risks of infection, and loss of sexual function [1-4]. Further, SCI drastically affects a person's sense of identity, ability to participate in meaningful life activities, and quality of life (QOL) [5-8].

Edward J. Rohn

ejrohn@oakland.edu

1 Department of Interdisciplinary Health Sciences, Oakland University, Rochester, MI, USA

2 Center for Innovation to Implementation, VA Palo Alto Health Care System, US Department of Veterans Affairs, Menlo Park, CA, USA

3 Department of Physical Medicine and Rehabilitation, University of Michigan, Ann Arbor, MI, USA
Together, these challenges have been shown to have profound negative effects on psychological health, including depression, anxiety, and isolation [2, 9-11]. While the process of coping with the results of SCI has focused traditionally on identifying and addressing maladaptive behaviors and barriers, a positive psychology approach to understanding coping focuses on positive traits and abilities. In fact, studies have found that the majority of patients with SCI demonstrate some form of resilience, or the ability to adapt to negative events [12-14].

Support for an explicit association between SCI and psychological resilience comes from Quale and Schanke [15]. They define resilience as a combination of low levels of psychological symptoms, such as anxiety and depression, and consistently high levels of positive affect. The construct has also been defined as an ability to flourish in the face of negative life events [16], and has been shown to mitigate the impact of SCI, leading to improved functional, psychosocial, and health-related outcomes [12, 14-17]. Two requirements are noted in the literature as important in defining resilience: (1) exposure to significant adversity such as SCI; and (2) a 
positive developmental outcome must have occurred following this exposure [12, 18-20]. Further, the construct is dynamic and processual, changing and adapting over time, and encompassing both behavioral and psychological aspects leading to positive adaptation [20].

Following on the framework of resilience model (FRM) $[18,19]$, resilience is predicated on the presence of key environmental and interpersonal "protective factors" and "vulnerabilities", which decrease or increase the probability of poor adaptation and coping outcomes following negative life events. These key factors play important roles in framing resilience in the context of other individual factors and characteristics, such as severity of injury, level of cognition and education. Factors in the FRM include individual differences (e.g., attitudes and appraisals, degree of self-efficacy, skill at problem solving), family support (e.g., parental bonds, romantic partner support, socioeconomics of the family), and support systems outside the family (e.g., nature of social networks, outside interests, peer relationships) [18]. Those with SCI who demonstrate high instances of protective factors tend to demonstrate high resilience to their injury circumstances, and are better able to deal with the issues they face, show greater acceptance of challenges, and a fighting spirit in overcoming limitations [12-14]. In particular, those with high resilience at onset of SCI tend to demonstrate better adaptive responses and maintain high resilience despite future challenges [14, 21]. Likewise, those with greater vulnerabilities demonstrate less resilience.

Although SCI-related resilience is explored in detail in the literature, that literature tends to focus most often on quantitative measurement and correlation [9, 14, 18, 22-28], with patient narratives less often appearing in print. The purpose of this article is to illustrate lived evidence of resilience as it unfolds using a narrative approach during the various stages of adjustment following injury. Better understanding of the resilience construct can assist clinicians in gaining further insight into the psychological process of adjustment after SCI, enabling them to more fully understand the ways in which some persons with SCI manage significant impairment. Further, resilience patterns can help explain the reasons persons with SCI sometimes report relatively stable life trajectories and health levels of psychological and social functioning [9, 19, 22]. Because thoughts and behaviors contributing to resilience are seen as modifiable, these can be improved by interventions designed to enhance self-management, self-efficacy, and positive adaptation after injury [29].

\section{Case presentations}

Case presentations derive from qualitative data collected as part of two mixed methods studies on the lived experiences of SCI. Participants for the two studies were recruited through a major Midwestern medical system and nearby VA hospital. Purposeful, criterion-based sampling was used in both studies [30]. A representative sample of time since injury and neurological level of impairment was sought in order to capture a range of participant experiences. The two women presented here were the only individuals involved in both studies. Each woman engaged in two semistructured interviews, one in each study, separated by $\sim 10$ years. Each interview lasted $80-90 \mathrm{~min}$. Interviewers were highly trained in qualitative interviewing techniques and well versed in psychosocial issues of SCI. Questions were openended to allow participants' own thoughts to emerge. Interviews were audio recorded and transcribed.

There was considerable overlap in the content of the two studies. The first study (Study $1 ; N=50$ ), conducted in 2002-04, elicited narrative responses of women with SCI around their ability to thrive based on social resources, personal strength and coping, and the impact of SCI on social roles and self-identity [31-33]. The second study (Study 2; $N=40$ ), conducted in 2014-15, investigated how persons with SCI (men and women) coped with neurogenic bladder and bowel (NBB) and elicited narrative accounts of NBB management routines and challenges, psychosocial factors, QOL, and the impact of complications such as incontinence and urinary tract infections (UTIs) [3, 34].

Our present dataset is comprised of the semistructured interviews for these two women, one interview each from each study. Text transcripts of the four interviews were coded using qualitative data analysis software (NVivo 10) [35] by highly trained coders. Codes were derived from the resilience literature, particularly protective factors, vulnerabilities, and the emergent themes from FRM of SCI-related resilience [12, 28]. Further, we adapted the resilience themes found in the qualitative study by Monden et al. [28] as codes to explore the comparability of those themes with our own. Those themes included psychological strength, social support, perspective, adaptive coping, spirituality/ faith, and role model/inspiring others.

The authors (two medical anthropologists and one rehabilitation psychologist) independently read the coded text, to begin identifying themes [36-39]. Potential themes were identified following a hybrid inductive-deductive approach to search for indicators of protective factors and vulnerabilities of resilience $[14,18,28]$. Intensive discussion of coded transcripts was used to reach consensus on key themes [40], which were either accepted or rejected on the basis of the available data and whether they were a credible reflection of two women's stories. Those interpretations most strongly supported by the data were deemed credible and included [40, 41]. A summary of characteristics of both cases, including resilience factors, trajectories, and life changes, appear in Table 1. 
Table 1 Summary of cases and characteristics related to resilience construct.

\begin{tabular}{|c|c|c|c|}
\hline & Resilience factors & Life changes & Resilience trajectories \\
\hline $\begin{array}{l}\text { Mary } \\
\text { - } 27 \text { years old at injury } \\
\text { - } 53 \text { years old at Study } 1 \\
\text { - } 63 \text { years old at Study } 2 \\
\text { - Tetraplegia } \\
\text { - Motor complete } \\
\text { - Sensory incomplete } \\
\text { - Single (separated) } \\
\text { - High school diploma }\end{array}$ & $\begin{array}{l}\text { - Main provider for children } \\
\text { - Strong religious faith } \\
\text { - Family support } \\
\text { - Peer advocacy } \\
\text { - Limited government insurance }\end{array}$ & $\begin{array}{l}\text { - Grandchildren } \\
\text { - Loss of hand/arm strength } \\
\text { - Started own business } \\
\text { - Waning health; more UTIs }\end{array}$ & $\begin{array}{l}\text { - High degree of personal strength derived } \\
\text { from faith } \\
\text { - Actively managed social support to prevent } \\
\text { dependence } \\
\text { - Resilience through giving back to the SCI } \\
\text { community } \\
\text { - Loss of independence over time due to age and } \\
\text { loss of strength }\end{array}$ \\
\hline $\begin{array}{l}\text { Ruth } \\
\text { - } 35 \text { years old at injury } \\
\text { - } 40 \text { years old at Study } 1 \\
\text { - } 52 \text { years old at Study } 2 \\
\text { - Tetraplegia } \\
\text { - Motor complete } \\
\text { - Sensory complete } \\
\text { - Single (divorced) } \\
\text { - } P h D\end{array}$ & $\begin{array}{l}\text { - Education and career } \\
\text { - Individual, career-minded } \\
\text { - Family support } \\
\text { - Generous private health } \\
\text { insurance } \\
\text { - 24-hour nursing care }\end{array}$ & $\begin{array}{l}\text { - Divorce from husband } \\
\text { - Contemplates career change } \\
\text { - Becomes rehab psychologist } \\
\text { - Healthy between studies }\end{array}$ & $\begin{array}{l}\text { - Focuses on career development as individual } \\
\text { strength } \\
\text { - Self-reflective of her changes and } \\
\text { accomplishments over time } \\
\text { - Develops an independent lifestyle through 24-hour } \\
\text { nursing care } \\
\text { - Less risk of loss as she ages due to nursing care }\end{array}$ \\
\hline
\end{tabular}

\section{Mary's story}

Mary was an African-American woman, born in Florida, and lived in Michigan since her late teens. In the late 1970s, she was a young divorcee with two small children, working three jobs to support her family. At 27, in 1978, she was involved in an automobile accident while traveling in Iowa. Her son was killed, her daughter sustained minor injuries, and Mary was paralyzed (motor complete, sensory incomplete tetraplegia). Unable to leave her hospital bed for many weeks, a lengthy rehabilitation followed. She received initial care at a small rural hospital. Once medically stable, she was transferred to a larger hospital for rehabilitation in Florida, close to her extended family. SCI treatment during the 1970s was much less advanced than today's clinical care. Her long-term prognosis was poor. Her healthcare team was not optimistic about her ability to recover and live independently.

Immediately following her injury, family members came to the hospital to support her. However, throughout her physical and occupational therapy, she resisted assistance from nurses and family, determined to learn to act independently again. She recalled actively waving away her father's offers for help and demanding to do things like eating by herself, no matter how long it took. Mary referenced her Christian faith as a source of strength during her rehabilitation, aiding her in coping with the early life changes following SCI. Once her inpatient rehabilitation was complete, she returned to Michigan with her daughter to resume their lives.

At the time of her first interview (2004), Mary was 53 years old, and 26 years post injury. Here, Mary reflected on the start of some physical slowdown of her body. She detailed how her bladder and bowel management, something she took pride in accomplishing on her own, was becoming more difficult. She imagined a time in the future where she would need assistance. In terms of participation in the wider community, Mary spent most of her days out of the home, working for the local center for independent living and participating in spinal cord advisory boards at the local hospital. Her involvement in the SCI community was a clear source of pride, connecting her to a higher purpose of helping others. Finally, she cited her close family relationships, including occasionally watching her grandchildren overnight. The description of her family bonds suggested a dynamic where she provided care rather than received it.

At the time of her second interview (2014), Mary was 63 -year old, having lived with her injury for 36 years. She owned her own company, providing peer consultation services to others with SCI, especially African-American women. Further, she was an advocate for the rights and benefits for those with SCI living in poverty. Her inner strength seemed to come from her willingness to give back to others, sharing what she had learned during her difficult life. Together, her work showed both her high level of resilience and her competence following SCI, but she also referenced the protective, supportive effect of this work in providing for her own emotional need to give back.

Mary's approach to life communicated a sense of strong self-efficacy-competency and a need to do for herself (independence) and give back to others, rather than rely on others to meet her immediate physical or medical needs. This self-efficacy enabled her to overcome challenges without formal caregiving. For example, despite her level of injury and functional limitations in her hands, she took 
pride in the fact that she had taught herself to selfcatheterize by weaving the catheter through her fingers in order to hold is securely. She was able to drive herself to places and did her own bowel program with minor help to transfer to the bedside commode. Together, these creative self-management techniques showed a high degree of problem-solving skill and self-efficacy.

In Study 2, Mary revealed that she had gradually and increasingly been experiencing bodily changes she alluded to in Study 1, leading to further hand weakness and increased UTIs. Declining arm strength and shoulder pain made her transfers and her ability to move independently in her wheelchair an increasing challenge. Her bodily decline challenged her ability to drive herself (in her adapted van), to socialize, and to work as she did before. In spite of these stressors, she denied any feelings of depression. Instead, her sense of responsibility toward helping others with SCI, especially young African-American women, and her own family support were significant sources of resilience. Besides signs of adaptive coping and high self-efficacy, a sense of gratitude shaped her new self as she aged with SCI. During the interview, she expressed feeling blessed for having such good physical and psychological health for as long as she had.

Of note, Mary's healthcare needs were covered by Medicaid and Medicare, government-supplied insurance in the United States for those economically disadvantaged and elderly (respectively). Her insurance coverage was limited, and as such, she was very conscious of the costs associated with her care as she aged. Her new challenges meant an increasing loss of independence and the increased need for regular assistance from a caregiver, which threatened to impact her financial livelihood, and thus contested her resilience. Up to her second interview, she was able to make adaptations to maintain her independence. As she aged, she was no longer able to adapt as well. Nevertheless, she continued to solve problem in face of these new challenges reaching out to her community of friends, colleagues, and professionals who served her asking for information on her new medical complications and resources to address these. Mary passed away from undisclosed medical complications in 2017, after being bed ridden for several months. During this time, she remained engaged in community activities and participated in meetings via conference calls. She stayed close to her daughter and her brother who both served as caregivers later in life, until her passing.

\section{Ruth's story}

Ruth is a Caucasian woman who grew up in Michigan. She described her early adulthood as one of exploration and learning what she wanted to do with her life. In her 20s, she earned a degree in business and began work as a consultant.
She described her 30s as a time of settling in, meeting her husband, and furthering her career. At 35, in 1997, she was involved in a rollover accident, where she was ejected from the automobile, and left paralyzed (motor and sensory complete tetraplegia). Her early experiences in rehabilitation were especially challenging. For example, she described herself as a communicator. Being dependent on oxygen support early on prevented communication challenged her sense of competence and ability to successfully cope with her losses. These initially negative appraisals led her to contemplate giving up. With time, she realized that her husband and family needed her and she would choose to live; "I can always choose to die later." Ruth explained that once she made this decision, she quickly came to see her injury as a new challenge to overcome, motivated by a strong desire to get back to work. In rediscovering her positive appraisal, her positive mood and motivation served as early protective factors of positive adaptation, overcoming the initial despair from her injury.

Ruth's resilience was challenged by interpersonal and environmental burdens following her injury. For the first 6 months, Ruth and her husband lived in an extended stay hotel while contractors remodeled their home to accommodate her physical needs. This move placed considerable strain on their marriage, as both struggled to adapt to Ruth's injury. Her husband often demonstrated active aversion to her bowel and bladder management programs. For example, catheterizing equipment would have to be out of sight and not left around in their bathroom. He did not want to discuss or be involved in her bowel or bladder care. Ruth spent a lot of time worrying about the sexual limits on her marriagewhether her husband was fulfilled. Under the continued stress, Ruth and her husband eventually divorced.

At the time of Study 1 (2002), Ruth was 40 years old, and 5 years post injury. She had established her own business doing case management with nurses serving those in the community with disabilities. Starting this business, negotiating her divorce, and returning to school were all additional stressors on her life. She approached these stressors with a determination, again sourced from her individual character and supported by the socioeconomic advantages of her insurance coverage. Further, she was in her second year of a master's program in rehabilitation counseling. Ruth explained that she was motivated to start her own business and return to school out of a desire to contribute to the bettering of the lives of those with disabilities. However, it appears her own determination, a desire to "never be bored," and an identity shaped by overcoming challenges likewise facilitated her resilience.

At the time of her second interview (2014), Ruth was 52 years old, having lived with complete tetraplegia 17 years. Ruth continued her education in rehabilitation counseling, completing doctoral work in 2005 in a major 
state university. Throughout her schooling, she developed strategies for managing her bladder needs in public, locating accessible restrooms, and due to her insurance was able to afford nursing care to accompany her to her classes. She moved from Michigan and became a faculty member at a major university in another state. Since her first interview, she also underwent an elective urinary diversion surgery to simplify her catheterization, which, with the help of her caregiver, greatly increased her independence. Ruth's career trajectory had moved from one of business to case management, and then to academia in direct response to her injury experiences and opportunities.

Ruth had been relatively healthy since her injury, without limiting complications or secondary health conditions to hinder her career or personal aspirations. She cited her ability to adapt, her determination, and her take-charge approach to life as secrets to her success-all factors in keeping with the protective adaptive features of resilience. She had become a successful teacher and mentor. She had secured significant concessions to her needs at work; her employer making sure she had a bathroom and rest place near each of her classrooms. Ruth's energy was focused less on independent self-management-she was well aware that, even with the diversion surgery, she would always need caregiver assistance for her bladder and bowel. Instead, she focused more on fulfilling broader personal and professional goals. Ruth developed an acceptance of dependency on caregiving that worked well for her.

It is worth noting that in the United States, automobile insurance covers some of the medical costs and rehabilitation services needed following an accident. However, coverage levels are determined by state policy and not all states provide the same coverage. Ruth's accident happened in Michigan. At the time of her accident, Michigan automobile insurance policies included "catastrophic coverage" that provided for all of Ruth's medical and rehabilitation needs, including outpatient therapies, adaptive transportation and housing, assistance with vocational and educational training, and 24-h caregiving. Because Mary's injury occurred in a state without this level of catastrophic coverage, these financial resources were not available to her. Catastrophic insurance coverage meant Ruth's prognosis for independent living and participation in the community was relatively better than Mary's given here reliance on the public benefits systems. From a financial perspective, Ruth had choices not available to Mary.

As Ruth continues to age, new medical issues have occurred requiring additional treatments but none has been life threatening. Further, she espoused no depression or anxiety over her circumstances, health, or work, considering herself as always being "positive." In addition to access to excellent care through her life, her own knowledge and professional judgment have led her through a successful life course providing her with a strong sense of self-efficacy.

\section{Themes of long-term resilience}

We identified four resilience themes that were (1) shared by both women, and (2) demonstrated change between the two studies. These themes include leveraging individual strength, managing social support, engaging in life beyond SCI, and adapting to SCI-related challenges. Tables $2-5$ provide demonstrative narrative examples from each interview, by case and by study. Below, we define each theme and compare the women's experiences.

\section{Leveraging individual strength}

This theme captures moments wherein each woman referenced protective resilience factors in the form of her own internal state, worked to leverage self-efficacy in her own care or wider life, or reflected on the source of individual strength.

As shown in Table 2, Mary's response to rehabilitation was to leverage her individual strength in a desire for personal independence. Overly relying on family support would leave her vulnerable to become dependent. Mary's determination to be independent seems possibly associated with her ability to appraise negative events as challenges that can be overcome, her self-efficacy displayed by her ability to solve problem and adapt when faced with very limited financial options. By Study 2, she demonstrated how her self-determination led her to solve her problems in a proactive way. Further, faith fueled her acceptance and positive attitude, her self-determination, and proactive selfefficacy—without it, she said, "I probably wouldn't even be sitting her." Spirituality is a factor shown to significantly predict post rehabilitation QOL [42]. As a result, Mary leveraged her Christian faith as a source of resilience. She worked beyond her own needs to inspire others to achieve this same level of strength and adaptation.

Ruth also demonstrated psychological strength in her initial recovery and life after SCI (see Table 2). She projected a self-image that focuses on her personal determination, citing her bravery, strength, and acceptance. A clear difference of the 12 years between her interviews is the ability to reflect on her journey. In Study 1, her narrative describes her path as a natural result of events and interactions among her positive personal style and strength, environmental and situational factors. By Study 2, she had learned to navigate this new dynamic by becoming more competent in articulating her own needs and while receiving considerable personal assistance and financial resources to make up for her losses. In contrast to Mary, she developed a 
Table 2 Leveraging individual strength theme examples by case and study.

\begin{tabular}{|c|c|c|}
\hline & Study 1 (2002-04) & Study 2 (2014-15) \\
\hline Mary & $\begin{array}{l}\text {...if I continued to let everybody do it for me all the time, I } \\
\text { would never do it myself... But then that's the kind of } \\
\text { person that I am. I believe that even though they say it can't } \\
\text { be done, if I try hard enough, I can do it. } \\
\text { And I've always had a strong faith in God... but after this } \\
\text { accident, I think it - well, no, I know that it helped to really } \\
\text { increase my faith and really trust Him very much. I learned } \\
\text { that God does not make any mistakes. }\end{array}$ & $\begin{array}{l}\text { I would say the secret would be accenting the positives and } \\
\text { trying to take care of the negatives. Don't get so caught up } \\
\text { in all of the problems, but be aware of them and try and find } \\
\text { solutions. And then it's just being grateful and thankful... } \\
\text { I think my faith, my positive attitude and my strong will. If I } \\
\text { didn't have that I probably wouldn't even be sitting here } \\
\text { talking to you because the doctors had said when I first got } \\
\text { hurt, "Put her in a nursing home. She's not going to be } \\
\text { doing anything for herself or anybody else." }\end{array}$ \\
\hline Ruth & $\begin{array}{l}\text {...people suspected that I was in denial and I don't really } \\
\text { think that I ever was and they were waiting for me to crash. } \\
\text { And five years later, I really never have. So, either I've been } \\
\text { in denial for five years or I just learned to accept it real fast. } \\
\text { But I kept telling myself it was going to be all right and that } \\
\text { I would be able to deal with it so I... tried to rationalize my } \\
\text { way through it and not be too stressed out... I think that I'm } \\
\text { a really brave and strong person and that I really } \\
\text { persevere... It's just the way I am... }\end{array}$ & $\begin{array}{l}\text { I'm very, very resilient and I think that that's what I can } \\
\text { attribute to be adjusted to a level of where I'm at. Believe } \\
\text { me, it did not happen overnight. It took years... I really do } \\
\text { push myself hard, so I think that my personality, being as } \\
\text { driven as I am, has really helped me. } \\
\text { I think that it's just a normal process of desensitization, just } \\
\text { the human adaption. I can't think of anything special that } \\
\text { happened. Again, I just think that it was a process over time } \\
\text { that occurred... Life goes on. }\end{array}$ \\
\hline
\end{tabular}

Table 3 Managing social support theme examples by case and study.

\begin{tabular}{|c|c|c|}
\hline & Study 1 (2002-04) & Study 2 (2014-15) \\
\hline Mary & $\begin{array}{l}\text {...sometimes your family can be so loving and so supportive } \\
\text { that they really hamper your growth or your progress ... } \\
\text { They don't want to see you struggle or to see you suffer to } \\
\text { accomplish what you have to accomplish. } \\
\text { And my dad literally started crying and says, "Daughter } \\
\text { don't do this! You don't have to do this. We're going to take } \\
\text { care of you..." But I told him that this was just something } \\
\text { that I wanted to do, even if I couldn't do it the way that I } \\
\text { used to do it... if I continued to let everybody do it for me } \\
\text { all the time, I would never do it myself.... }\end{array}$ & $\begin{array}{l}\text { Even recently I got some dysreflexia cards and gave them to } \\
\text { all the members of family, my daughter, my sister, all my } \\
\text { brothers, my father. Most of them are out of state, but I want } \\
\text { them to know if I'm there and these kinds of things start to } \\
\text { happen this is what you need to do. } \\
\text { I've been able to just be open about everything... I mean it's } \\
\text { a part of you. I always say to people, your disability does } \\
\text { not define who you are, but it's just a matter of letting } \\
\text { people know what that all involves. So why should I not } \\
\text { make them aware and make them knowledgeable? }\end{array}$ \\
\hline Ruth & $\begin{array}{l}\text { [My family are] all very open about helping me with my } \\
\text { care... They understand the physiology behind the injury } \\
\text { and, as a matter of fact, all were taught to cath me. } \\
\text { Especially my sister has learned how to cath and do the } \\
\text { bowel program because she felt it was very important. } \\
\text {...there were a ton of things I did because [my husband] did } \\
\text { not want to be reminded of the injury... So, his way of } \\
\text { dealing with it was to ignore as much of it as he could. So, I } \\
\text { was very secretive. I would not use the word "cath." That } \\
\text { word was not to be spoken. If we were in the bathroom and I } \\
\text { was draining my leg bag, I didn't want the sound of the } \\
\text { water entering into the toilet. }\end{array}$ & $\begin{array}{l}\text { I did have [a peer counselor]... and he was able to tell me, } \\
\text { "Yeah, it gets better in time. You'll be able to stay in the } \\
\text { chair more than a couple of hours without feeling like you're } \\
\text { going to die." I think peer counseling is probably one of the } \\
\text { most helpful things that any individual with a spinal cord } \\
\text { injury or traumatic injury can have. } \\
\text { It just gave me the opportunity. [My insurance company] } \\
\text { offered to pay for my master's to go back to school, and } \\
\text { then of course [my mentor], when I wanted to stop and not } \\
\text { go back to school, she wouldn't take no for an answer. She } \\
\text { wanted me to get my PhD and so she really pushed to get } \\
\text { that training fellowship... }\end{array}$ \\
\hline
\end{tabular}

much stronger sense of interdependence on others early on based on these interactive factors. Yet she reflected on how her resilience "did not happen overnight" but instead was a dynamic and interactive process. She normalized her adaptation; at one moment referencing the years it took to adjust to her SCI and the next claiming her adjustment as a normal part of human experience.

In summary, leveraging individual strength allowed each to minimize their vulnerabilities and find resilience in the days and years following SCI. Each woman demonstrated positive self-efficacy, reported in the days following their injury and demonstrated in their attitudes toward their injury. Both framed their injury experiences as challenges and worked proactively to overcome them. Mary's strength came from her strong personal self-identity and her ability to thrive on helping others while leveraging her family support, social and professional contacts, and spiritual faith as sources additional strengths. Though Ruth does reference her faith in Study 1, her strength appears to come more from her own self-image of being a certain kind of person. Their statements dovetail 
Table 4 Engaging in life beyond SCI theme examples by case and study.

\begin{tabular}{|c|c|c|}
\hline & Study 1 (2002-04) & Study 2 (2014-15) \\
\hline Mary & $\begin{array}{l}\text { I'm really involved with a lot of organizations that have to } \\
\text { do with the disabled community because I firmly believe } \\
\text { that we all have to work together in order to make things } \\
\text { better for those of us who need them. } \\
\text { It just does my heart good to pull up in the driveway and my } \\
\text { grandkids come running out, "Granny, Granny, Granny, } \\
\text { Granny!" That's another one of those rejuvenation kind of } \\
\text { things. And then I take time and spend time and keep them. }\end{array}$ & $\begin{array}{l}\text { The prognosis really wasn't that good, but I have according } \\
\text { to the doctors surpassed way beyond anybody's belief; } \\
\text { totally independent, very active at work in the community } \\
\text { work and the job field. I own my own company; involved in } \\
\text { a lot of organizations... } \\
\text { I live. I don't just exist day to day. I'm busy. I'm active in } \\
\text { my community. I wake up every morning wanting to get the } \\
\text { day started. I love what I do. I think that I make a difference } \\
\text { in my community and other people's lives. So those kinds of } \\
\text { things help me to feel better about myself... }\end{array}$ \\
\hline Ruth & $\begin{array}{l}\text { I love school, I love what I'm doing. I'm in my second year } \\
\text { of my master's program in rehab counseling... It's one of } \\
\text { the best in the country and I understand why, because the } \\
\text { professors that oversee the program are just fantastic, } \\
\text { phenomenal people. } \\
\text { I am doing so much more than I really would have thought } \\
\text { possible... My life has been so full and interesting and I'm } \\
\text { always changing... Looking back on the past and how my } \\
\text { life has been, I can't imagine what my future holds because I } \\
\text { feel like there's so much out there... }\end{array}$ & $\begin{array}{l}\text { I'm totally empowered; I love what I do. I teach, I do } \\
\text { research, I'm totally independent socioeconomically and } \\
\text { I'm pretty solid... I've achieved everything that I wanted to } \\
\text { achieve in my life and more. I've actually exceeded my } \\
\text { expectations of what I thought my life would be. And to be } \\
\text { honest with you, had I not had the spinal cord injury I don't } \\
\text { know that I would be saying that. } \\
\text { It took, I would say, a solid year to make any adjustment } \\
\text { whatsoever and then probably over a five-year period to } \\
\text { where I felt comfortable talking about it to non-family } \\
\text { members. That long. And now at this point, like I said, I talk } \\
\text { to a classroom full of students. }\end{array}$ \\
\hline
\end{tabular}

Table 5 Adapting to SCI-related challenges theme examples by case and study.

\begin{tabular}{|c|c|c|}
\hline & Study 1 (2002-04) & Study 2 (2014-15) \\
\hline Mary & $\begin{array}{l}\text { My theory is prevention is better than trying to be cured so if } \\
\text { we can be preventive and prevent things from happening, } \\
\text { then we don't have to worry about this long process of } \\
\text { going through the curing process. } \\
\text { I'm an optimist but I'm also a realist. I realize that I was not } \\
\text { going to continue at the pace that I continued the last } 20 \\
\text { years or the last } 15 \text { years or so. When [hand and arm } \\
\text { weakness] first started happening about three or four years } \\
\text { ago, you know, I had to stop and take check... I'm still a } \\
\text { very healthy person, a very happy person mentally. }\end{array}$ & $\begin{array}{l}\text { And I always try to be proactive instead of being reactive... } \\
\text { I used to could go out and be gone for seven or eight hours } \\
\text { during the day and not have to cath. I was diapered down } \\
\text { and still drinking water and stuff, but I wouldn't get any } \\
\text { kind of ill feelings or feel bad with hyperdysreflexia and } \\
\text { things. So after things started changing I still wanted to be } \\
\text { able to go out in public... So it was just a matter of finding } \\
\text { out how to do that. } \\
\text { I do have a problem sometimes when I come home because } \\
\text { I do all of my care and do everything myself...You've got to } \\
\text { do what needs to be done to keep you healthy and keep your } \\
\text { body working like it needs to work... It's just a matter of } \\
\text { making those adjustments where you can still continue to } \\
\text { have a great quality of life... }\end{array}$ \\
\hline Ruth & $\begin{array}{l}\text { And what it really took is me to understand that the bowel } \\
\text { and the bladder are physical functions of your body. They } \\
\text { aren't who you are. And it's a limitation, yeah, but it doesn't } \\
\text {-it's not about me and it doesn't-it's not about my ego... } \\
\text { just something that I think I was embarrassed of and } \\
\text { ashamed of. } \\
\text { Oh, I think that my life, again, because of the auto insurance } \\
\text { and the coverage and the benefits, I think that my life is } \\
\text { pretty much as good as it can get, living with a spinal cord } \\
\text { injury. I'm working out, I'm improving my health, I'm } \\
\text { getting stronger, I'm getting smarter. }\end{array}$ & $\begin{array}{l}\text { But generally, both my bladder and bowel are very, very } \\
\text { stable so I really don't have issues. I do have } 24 \text {-hour } \\
\text { nursing, so I have a nurse that travels with me and I do } \\
\text { intermittent catheterization every two to three hours as } \\
\text { needed, and then the bowel program every other night. } \\
\text { Does [my bowel program] stop me from doing things? No. } \\
\text { This weekend I'm going to the theater and seeing a play. } \\
\text { But it does impact. It's not the same as it was before my } \\
\text { injury. I'm certainly not probably as spontaneous about } \\
\text { things. I definitely do plan ahead more. }\end{array}$ \\
\hline
\end{tabular}

with definitions of resilience that include "the ability to flourish" [16] and a "fighting spirit" [12, 13]. In Ruth's case, however, the dynamic interactions with external resources is clearly another source of strength and resilience.

\section{Managing social support}

This theme captures the nuanced way in which Mary and Ruth each interfaced with the people in their lives, and 
actively managed the way family and friends did or did not assist them in their SCI recovery and care.

In Table 3, Mary's responses indicate the importance of love and support from her family early in her rehabilitation, but she reiterates her drive for independence. Mary seemed to frame reliance on family not as protective, but as a potential vulnerability. She indicates her appreciation of what her family wants to do for her, but worries this could hamper her growth. Later in Study 2, her focus had shifted to educating those in her social circle, especially her family, to better understand her SCI complications-especially dysreflexiaand what to do in the event that she needs help. She maintained her independence across the years between her injury and her final interview, though she did reference her aging body and waning hand strength as cause for concern, recognizing her likely need for future support (especially in managing her bladder and bowel). Her attachment to her family is evident, but she maintains her self-efficacy by taking an educational role rather than the role of care recipient.

Table 3 provides evidence how Ruth also actively managed the social support she received from friends and family. In Study 1, she indicated how open her family is to understand her injury and how all of her family members were taught to catheterize her. Ruth was willing to let others care for her, in part because she had the resources to pay for 24-h nursing care, and because she was never able to do her bladder and bowel regimens herself. Despite Ruth's openness, while they remained married, her husband showed strong aversion to anything related to her bladder or bowel care, contributing to their eventual divorce. Overall, Ruth served a managerial role in her care. She could then focus on other aspects of her life, especially by Study 2, where she describes the social support she received from peer counseling and the encouragement she received from her mentors. In this way, the management of her social support for her SCI needs seemed complete and she could focus on other goals beyond her injury.

Each woman's descriptions of their social support conform to common definitions of resilience. Both had social support; those who took active roles in helping adapt to SCI and enjoy broader life. Our data show how both women had complex relationships with their social support networks and experienced changes in that support over time. Where Mary shifted between interviews to a more educational role serving as a role model to others, Ruth was willing to allow others to provide her care so she could focus on other things.

\section{Engaging in life beyond $\mathrm{SCl}$}

This theme captures the ways in which Mary and Ruth each participated in their social domains-particularly meaningful work - and acted to minimize the impact of physical disability on participation.
At the time of her injury, Mary was working three jobs in order to provide for her family. She served the role of provider for her children and we conject that her determination during rehabilitation was a result of a need to resume that role. She would not accept the role of care recipient unless absolutely necessary, focusing instead on resuming her role as provider. As seen in Table 4, she had become a grandmother and gained "rejuvenation" from spending time with her grandchildren. She had also become involved in the "disabled community," working as a peer mentor and advocate. By Study 2, she had leveraged her community service into a successful company. Developing this company showed innovation and strong problem-solving skills, indicators of high resilience. Therefore, over the trajectory of her narrative, her role as caregiver-to both family and her communityprovided protective factors to her resilience, transforming the challenges of SCI and an aging body into meaningful work in the SCI community.

Ruth's focus was quite different (see Table 4). While she also diverged from the work she had been doing prior to her injury, she continued to focus on personal growth through education and a career in academia. She credits her injury, as well as the mentors she met along the way, as inspiring her decision to become a rehabilitation counselor and educator. Her meaningful work was in providing counseling services for patients in rehabilitation, but she framed the impact on her resilience by what this career path provided her-empowerment and achievement-rather than what she would provide the community. Many of her opportunities stemmed directly from the financial support she received from her insurance, which she leveraged into a career that provided for all her financial needs. After following this path, she was able to engage in the community to educate others about her injury.

Both women worked their entire lives, yet each engaged in a life beyond her injury in a different way. Mary focused on family and giving back to the disability to community, with an apparent outward focus. Ruth focused inward, on how her career could empower her, and took inspiration for her new career path from her injury. Despite their respective rationales for the work each did, each woman's work was a protective factor in their resilience, which became a significant part of their identity.

\section{Adapting to SCl-related challenges}

This theme explores the daily strain of having an SCI and how each woman actively adapted as each went about working, aging, and engaging in daily life.

Overall, Mary used a prevention approach to her SCI and overall health. In Table 5, she begins by discussing how it is easier for her to take care of health problems before they happen to avoid the long recovery that may follow, for example, a bedsore or issues of dysreflexia. At the time of 
Study 1, she also had begun experiencing changing due to age. She had begun noticing weakness in her hands that challenged her ability to self-catheterize, which in turn threatened her need to be independent. Later, in Study 2, these changes had continued and she was also experiencing more loss of bladder control. Further, she reflected on the strain of doing all her care alone. Taken together, her changing health circumstances challenged the protective factors of her individual strength, putting her in a place to rely more and more on her family members for her care at the end of her life.

Because of her insurance benefits, including 24-h nursing care, Ruth's resilience was less at risk as she aged as compared with Mary. Table 5 also provides evidence on how Ruth was better able to frame her bladder and bowel function as issues separate from her self-image, as something that needed to be managed and not be ashamed of. She clearly references her considerable resources in managing her bladder and bowel needs. Mary demonstrated selfefficacy that included balancing her bladder and bowel management against her service in the community, while Ruth was willing (and financially able) to defer that care to nurses while she focused on her own career. Further, in seeking an elective diversion surgery, she was further able to facilitate how her bladder did not stop her from enjoying life. Neither nursing care nor elective surgery were choices Mary was empowered to make. The notion of aging with SCI was not a factor in our discussions with Ruth, whereas the changes to Mary's body-especially her ability to manage her bladder independently - were significant challenges.

\section{Discussion}

While much of the existing literature on SCI and resilience focuses on quantitative measures of resilience, it is unable to provide an in-depth understanding of the individual narratives and contextual factors that contribute to longterm resilience. To address this important gap, our findings provide a longitudinal perspective of two women living with SCI, allowing us to identify and explore resilience definitions and themes from the literature and to illustrate resilience as a process that changes over time in response to new challenges and opportunities as each aged [32, 43-46]. Each woman's narrative support trends in the literature that show the deep personal and health-related benefits of resilience after SCI [12, 14-16, 21, 27]. However, we extend this literature by providing a more in-depth view of the process of resilience, as experienced across life trajectories. These trajectories described the dynamic interactions among their personal, environmental, and situational factors resulting in positive life outcomes after SCI.
The FRM [19] provided guidance for us to recognize protective factors and vulnerabilities. However, our data did not entirely map onto the categories in the FRM. Firstly, while both Mary and Ruth had clear individual differences serving protective roles in their resilience, each woman shaped a life for herself both within and outside the normative societal expectations of those with a severe disability, aspects our narrative data was able to highlight more fully. Secondly, their family support was clear, but our work shows the unique way in which each woman actively managed her social support networks to serve her needs. This moves beyond a simple binary of protective factor vs. vulnerability to show the nuanced way each woman engaged with her social milieu. Further, external factors, such as social support and access to resources, further facilitated each woman's ability to be resilient (though less so for Mary), creating a structural support upon which positive resilience could grow. We showed how the support systems outside the family were multidimensional and more complex as compared with the FRM.

Monden et al. [28] also informed our analyses by providing a qualitative study of a similar population and topic as our own, including themes that we could test against our own data. However, the themes identified by Monden et al. also did not entirely map onto the narratives of these two women. The themes from Monden et al. were focused more often on static concepts measuring the presence of factors only, such as social support, psychological strength, perspective, etc. Our themes more fully captured the processual nature of resilience-both Mary and Ruth changed over time, actively leveraging their individual strengths, managing their social networks, and adapting to challenges both SCI-related and in their respective communities. Finally, we also found spirituality to more of an individual protective factor, in keeping with the FRM, than its own thematic category, at least in terms of the saliency of the topic in our particular dataset.

Our results offer important lessons learnt and educational opportunities for clinicians to improve care for people aging with SCI, especially women. By using a novel, longitudinal approach that explores the intersection of aging and resilience, clinicians may benefit from education on ongoing needs assessments for people aging with SCI, especially when they exhibit highly resilient approaches to living with SCI. For example, Mary's story is especially important so that clinicians do not overlook the changing needs of people who are highly resilient. As Mary aged, she required more assistance with bladder management, which may not have been as well known because she was highly resilient (e.g., self-efficacy, family support, general wellbeing). For patients who have been independent and resilient, it is important to consider how aging challenges one's resilience resources over time and consider better ways of assessing 
and supporting people who may not have needed support in the past. Using their sense of independence and self-efficacy to learn new options for care is key to maintaining patient motivation and engagement in treatment.

There were important limitations in these case presentations. First, the fact that Mary's first interview took place nearly 30 years after her injury means we are relying extensively on her memory of those events. Regardless, her experiences at each interview were shaped by those memories. Second, Ruth's both interviews took place during highly stable periods of her life, perhaps leading her to overstate her resilience over time. Mary's second interview however was in a period of worsening health, yet her resilience remained high. Further studies would be needed to more fully explore the potential contributions of narrative accounts of resilience in SCI lived experience and care.

Because resilience can be found in many persons with SCI we encourage clinicians and researchers to explore and cultivate this ability to bounce back from adversity in ways such that it can be adapted and used throughout new life challenges. Researchers should consider how participant narratives of resilience provide a context for the understanding and interpretation of scores from resilience measures. Further, we who work to better understand and improve the QOL for those with SCI need to recognize that health goes beyond diagnosis and treatment; healing does not restore the person to a state of being prior to injury, but allows for the growth of a new person in its stead [47]. In this way, we-both clinicians and researchers-are empowered to help patients externalize and articulate their own narratives of resilience.

Acknowledgements The authors wish to thank the two women who shared their stories and experiences with us. They honor us with their trust and candidness. We hope that by disseminating this work, we honor them in return.

Funding This work was supported by the Department of the Army USAMRAA, Department of Defense (CDMRP) (\#SCI1 10228); by the National Institute on Disability and Rehabilitation Research (\#H113G020060); and by the National Institute on Disability and Rehabilitation Research (\#90AR5020-0200). The views expressed in this article are those of the authors and do not necessarily represent the views of the Department of Veterans Affairs.

\section{Compliance with ethical standards}

Conflict of interest The authors declare that they have no conflict of interest.

Ethical approval We certify that all applicable institutional and governmental regulations concerning the ethical use of human volunteers were followed at all times. Both women gave their permission to be included in this case presentation. Pseudonyms were used and identifying details omitted or modified to preserve anonymity.

Publisher's note Springer Nature remains neutral with regard to jurisdictional claims in published maps and institutional affiliations.

\section{References}

1. Barker RN, Kendall M, Amsters D, Pershouse KJ, Haines TP, Kuipers $\mathrm{P}$. The relationship between quality of life and disability across the lifespan for people with spinal cord injury. Spinal Cord. 2009;47:149.

2. Post MW, van Leeuwen CM. Psychosocial issues in spinal cord injury: a review. Spinal Cord. 2012;50:382-9.

3. Tate DG, Forchheimer M, Rodriguez G, et al. Risk factors associated with neurogenic bowel complications and dysfunction in spinal cord injury. Arch Phys Med Rehabil. 2016;97:1679-86.

4. Tate DG, Kalpakjian CZ, Forchheimer MB. Quality of life issues in individuals with spinal cord injury. Arch Phys Med Rehabil. 2002;83:S18-S25.

5. Frank G. Venus on wheels: two decades of dialogue on disability, biography, and being female in America. University of California Press; Berkeley, CA, 2000.

6. Luborsky MR. The cultural adversity of physical disability: erosion of full adult personhood. J Aging Stud. 1994;8:239-53.

7. Murphy RF. The body silent. WW Norton \& Company; New York City, NY, 2001.

8. Ramirez M, Altschuler A, McMullen C, Grant M, Hornbrook M, Krouse R. I didn't feel like i was a person anymore": realigning full adult personhood after ostomy surgery. Med Anthropol Quart. 2014;28:242-59.

9. Guest R, Craig A, Tran Y, Middleton J. Factors predicting resilience in people with spinal cord injury during transition from inpatient rehabilitation to the community. Spinal Cord. 2015;53:682-6.

10. Tate DG, Forchheimer MB, Karana-Zebari D, Chiodo AE, Kendall Thomas JY. Depression and pain among inpatients with spinal cord injury and spinal cord disease: differences in symptoms and neurological function. Disabil Rehabil. 2013;35:1204-12.

11. Tate DG, Forchheimer MB, Krause JS, Meade MA, Bombardier $\mathrm{CH}$. Patterns of alcohol and substance use and abuse in persons with spinal cord injury: risk factors and correlates. Arch Phys Med Rehabil. 2004;85:1837-47.

12. Alschuler KN, Kratz AL, Ehde DM. Resilience and vulnerability in individuals with chronic pain and physical disability. Rehabil Psychol. 2016;61:7.

13. Bonanno GA. Loss, trauma, and human resilience: have we underestimated the human capacity to thrive after extremely aversive events? Am Psychologist. 2004;59:20.

14. Bonanno GA, Kennedy P, Galatzer-Levy IR, Lude P, Elfstrom ML. Trajectories of resilience, depression, and anxiety following spinal cord injury. Rehabil Psychol. 2012;57:236-47.

15. Quale AJ, Schanke A-K. Resilience in the face of coping with a severe physical injury: a study of trajectories of adjustment in a rehabilitation setting. Rehabil Psychol. 2010;55:12.

16. Silverman AM, Molton IR, Alschuler KN, Ehde DM, Jensen MP. Resilience predicts functional outcomes in people aging with disability: a longitudinal investigation. Arch Phys Med Rehabil. 2015;96:1262-8.

17. Alschuler KN, Jensen MP, Sullivan-Singh SJ, Borson S, Smith AE, Molton IR. The association of age, pain, and fatigue with physical functioning and depressive symptoms in persons with spinal cord injury. J Spinal Cord Med. 2013;36:483-91.

18. Catalano D, Chan F, Wilson L, Chiu CY, Muller VR. The buffering effect of resilience on depression among individuals with spinal cord injury: a structural equation model. Rehabil Psychol. 2011;56:200-11.

19. Kumpfer KL. Factors and processes contributing to resilience. In: Resilience and development. Springer; New York City, NY, 2002. p.179-224.

20. Todd JL, Worell J. Resilience in low-income, employed, African American women. Psychol Women Quart. 2000;24:119-28. 
21. Kennedy P, Kilvert A, Hasson L. A 21-year longitudinal analysis of impact, coping, and appraisals following spinal cord injury. Rehabil Psychol. 2016;61:92.

22. Kilic SA, Dorstyn DS, Guiver NG. Examining factors that contribute to the process of resilience following spinal cord injury. Spinal Cord. 2013;51:553-7.

23. Livneh H, Martz E. Coping strategies and resources as predictors of psychosocial adaptation among people with spinal cord injury. Rehabil Psychol. 2014;59:329.

24. Min JA, Lee CU, Hwang SI, et al. The moderation of resilience on the negative effect of pain on depression and post-traumatic growth in individuals with spinal cord injury. Disabil Rehabil. 2014;36:1196-202.

25. Shin JI, Chae JH, Min JA, et al. Resilience as a possible predictor for psychological distress in chronic spinal cord injured patients living in the community. Ann Rehabil Med. 2012;36:815-20.

26. Victorson D, Tulsky DS, Kisala PA, Kalpakjian CZ, Weiland B, Choi SW. Measuring resilience after spinal cord injury: development, validation and psychometric characteristics of the SCIQOL resilience item bank and short form. J Spinal Cord Med. 2015;38:366-76.

27. White B, Driver S, Warren AM. Resilience and indicators of adjustment during rehabilitation from a spinal cord injury. Rehabil Psychol. 2010;55:23-32.

28. Monden KR, Trost Z, Catalano D, et al. Resilience following spinal cord injury: a phenomenological view. Spinal Cord. 2014;52:197-201.

29. Craig A. Resilience in people with physical disabilities. In: The Oxford handbook of rehabilitation psychology. Oxford University Press, New York, NY, USA, 2012. p. 474.

30. Palinkas LA, Horwitz SM, Green CA, Wisdom JP, Duan N, Hoagwood K. Purposeful sampling for qualitative data collection and analysis in mixed method implementation research. Adm Policy Ment Health. 2015;42:533-44.

31. Lequerica AH, Forchheimer M, Albright KJ, Tate DG, Duggan $\mathrm{CH}$, Rahman RO. Stress appraisal in women with spinal cord injury: supplementary findings through mixed methods. Int $\mathbf{J}$ Stress Manag. 2010;17:259.

32. Nevedal A, Kratz AL, Tate DG. Women's experiences of living with neurogenic bladder and bowel after spinal cord injury: life controlled by bladder and bowel. Disability and rehabilitation. 2016;38:573-81.
33. Tate D, Duggan C, Albright K, Epstein M, Jeji T, Lequerica A. Stress and coping over the life course: a perspective on women with spinal cord injury. Ann Arbor, MI: University of Michigan. 2006.

34. Rohn EJ, Tate DG, Forchheimer M, DiPonio L. Contextualizing the lived experience of quality of life for persons with spinal cord injury: a mixed-methods application of the response shift model. J Spinal Cord Med. 2019;42:469-77.

35. Castleberry A. NVivo 10 [software program]. Version 10. QSR International; 2012. Am J Pharm Educ. 2014;78.

36. Bernard HR. Research methods in anthropology: qualitative and quantitative approaches. Rowman \& Littlefield; Lanham, MD, 2017.

37. Braun V, Clarke V. What can "thematic analysis" offer health and wellbeing researchers? Int J Qual Studies Health Well-Being. 2014;9:9-10.

38. Luborsky MR. The identification and analysis of themes and patterns. In: Gubrium JF, Sankar A, editors. Qualitative methods in aging research. Newbury Park, CA, Sage focus edition, 1994. p.189-210.

39. Ryan GW, Bernard HR. Techniques to identify themes. Field Methods. 2003;15:85-109.

40. Shenton AK. Strategies for ensuring trustworthiness in qualitative research projects. Educ Inf. 2004;22:63-75.

41. Corbin J, Strauss A. Basics of qualitative research: techniques and procedures for developing grounded theory. Sage Publications; Newbury Park, CA, 2014.

42. Albright KJ, Forchheimer M, Tate DG. Spirituality and rehabilitation. 2010

43. Pentland W, Walker J, Minnes P, Tremblay M, Brouwer B, Gould $\mathrm{M}$. Women with spinal cord injury and the impact of aging. Spinal Cord. 2002;40:374-87.

44. Becker G, Newsom E. Resilience in the face of serious illness among chronically ill African Americans in later life. J Gerontol Ser B. 2005;60:S214-23.

45. Nevedal AL, Ayalon L, Briller SH. A qualitative evidence synthesis review of longitudinal qualitative research in gerontology. Gerontologist. 2019;59:e791-801.

46. Solomon P, Nixon S, Bond V, Cameron C, Gervais N. Two approaches to longitudinal qualitative analyses in rehabilitation and disability research. Disabil Rehabil. 2019;18:1-7.

47. Canguilhem G, Geroulanos S, Meyers T. Writings on medicine. Fordham University Press; New York City, NY, 2012. 